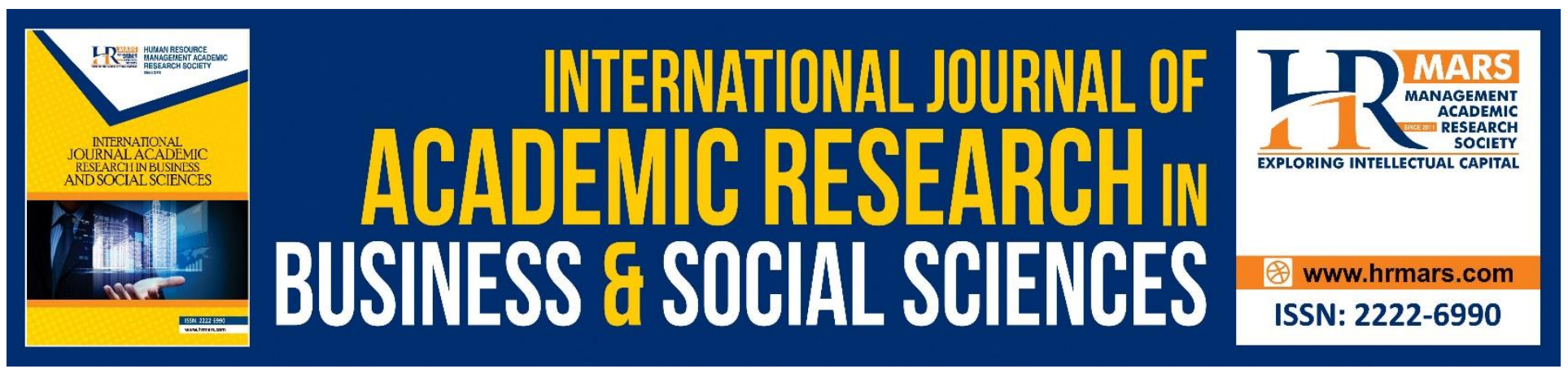

\title{
Elements of Transformation in Indie Publication from the Perspectives of Lejen Press Sdn Bhd
}

Siti Nor Fazira Jono, Mohd Syuhaidi Abu Bakar, Muhammad Aisamuddin bin Md Asri, Fazlina binti Jaafar, Nora Edrina binti Sahharil

To Link this Article: http://dx.doi.org/10.6007/IJARBSS/v10-i6/7341

DOI:10.6007/IJARBSS/v10-i6/7341

Received: 15 March 2020, Revised: 17 April 2020, Accepted: 11 June 2020

Published Online: 27 June 2020

In-Text Citation: (Jono et al., 2020)

To Cite this Article: Jono, S. N. F., Bakar, M. S. A., Asri, M. A. bin M., Jaafar, F. binti, \& Sahharil, N. E. binti. (2020). Elements of Transformation in Indie Publication from the Perspectives of Lejen Press Sdn Bhd. International Journal of Academic Research in Business and Social Sciences, 10(6), 666-673.

\section{Copyright: (c) 2020 The Author(s)}

Published by Human Resource Management Academic Research Society (www.hrmars.com)

This article is published under the Creative Commons Attribution (CC BY 4.0) license. Anyone may reproduce, distribute, translate and create derivative works of this article (for both commercial and non-commercial purposes), subject to full attribution to the original publication and authors. The full terms of this license may be seen

at: http://creativecommons.org/licences/by/4.0/legalcode

\section{Vol. 10, No. 6, 2020, Pg. 666 - 673}

Full Terms \& Conditions of access and use can be found at http://hrmars.com/index.php/pages/detail/publication-ethics 


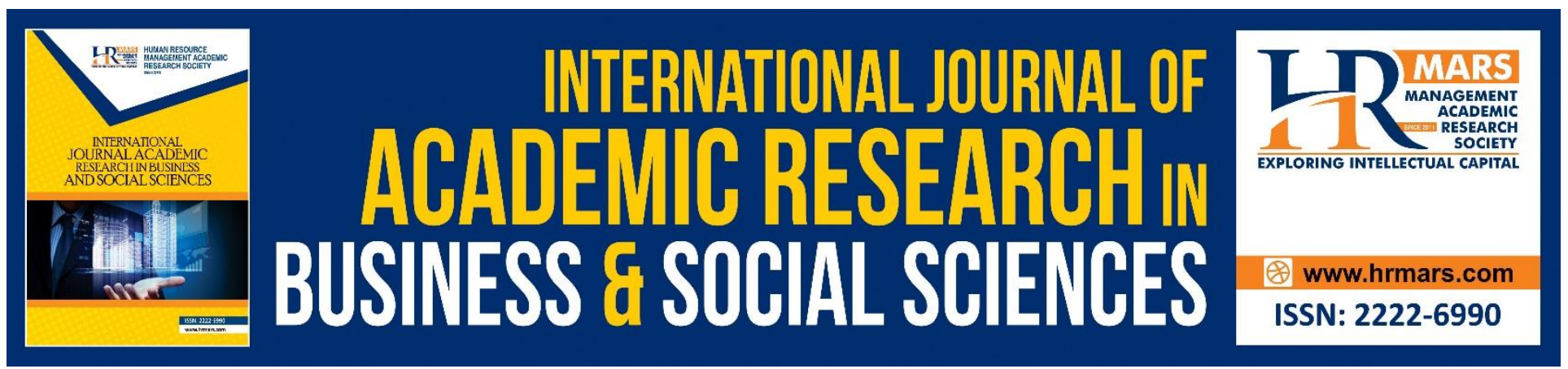

\title{
Elements of Transformation in Indie Publication from the Perspectives of Lejen Press Sdn Bhd
}

\author{
Siti Nor Fazira Jono \\ Faculty of Film, Theatre and Animation, Universiti Teknologi MARA, Malaysia \\ Email : sitinor.fazira@yahoo.com \\ Mohd Syuhaidi Abu Bakar \\ Faculty of Film, Theatre and Animation, Universiti Teknologi MARA, Malaysia \\ Email : syuhaidi@uitm.edu.my \\ Muhammad Aisamuddin bin Md Asri \\ Chief Executive Officer, Managing Director of Lejen Press Sdn Bhd \\ Email: aisalinglung@lejenpress.com \\ Fazlina binti Jaafar \\ Faculty of Art and Design, Universiti Teknologi MARA, Malaysia \\ Email: fazli535@uitm.edu.my \\ Nora Edrina binti Sahharil \\ Faculty of Film, Theatre and Animation, Universiti Teknologi MARA, Malaysia \\ Email: edrina@uitm.edu.my
}

\begin{abstract}
The Malaysian government aims to publish 31,700 book titles per year by 2020 to meet the standards of literate developing countries recommended by the United Nations Educational, Scientific and Cultural Organization (UNESCO). As such, publishing houses in Malaysia is taking steps to produce a variety of books to meet the government's target, including flourishing indie publications. This study discussed the transformation element in indie writing and book publishing in Malaysia from the perspectives of an indie publisher (Lejen Press Sdn Bhd). It was found that Lejen Press has transformed its business entity from printed media to digital media, emphasized openness and freedom of the work and has extended its book marketing strategies. This transformation helped the company excel in its visibility and market share in the publication industry in Malaysia.
\end{abstract}


INTERNATIONAL JOURNAL OF ACADEMIC RESEARCH IN BUSINESS AND SOCIAL SCIENCES

Vol. 10, No. 6, June, 2020, E-ISSN: 2222-6990 @ 2020 HRMARS

Keywords: Indie Publication, Transformation, Lejen Press, Mainstream Book Publishing, Indie Book Publishing, Books.

\section{Introduction}

The word Indie derives from the English word carrying the notion of independent, free and not dependent on each other. While looking at the word indie terminologically, it is said that it is rarely discussed by Malaysians in detail, said Wahab and Kusnin (2012). By 2011, indie publications had emerged in the Malaysian book industry and had collaborated in the publication of books. This had succeeded in attracting the attention of the local community. The total number of books published in 2011 reached 16,000, bringing Malaysia to 23rd out of 110 countries in terms of publication. The acceptance of indie publication was a big surprise to the book industry in Malaysia as indie books received a lot of attention from the local community, especially the younger generation. Indie books, with independent writing themes of relaxed style that touched the realities of community life, while also discussing both political and religious matters create a new mainstream acceptance (Wahab and Kusnin, 2012).

According to Masrom (2018), a novel in the form of indie works may threaten and damage the thinking of young people because the essence of the work produced by these indie writers is essentially using coarse language and adopted free-thinking style writing. The writer also noted further in the aspect of language style that constantly mix the Malay language with the English language. In addition, the use of the English language does not follow proper guidelines, such as the use of italics for English words in a Malay novel. Issues raised in regard to indie publishing have, in fact, begun with lack of use of proper language, the style of language used in a work and the storytelling style introduced by these indie writers.

However, indie's issues have been around for a long time now. Our country's National Laureate, A Samad Said published Salina, a novel that at the time was a great controversy, deals with the issues of prostitution. Subsequently, yet another National Laureate, Shahnon Ahmad wrote the novel Shit, dealing with issues of political unrest that are written in a non-narrative language in opposition to mainstream standards of the Dewan Bahasa dan Pustaka (DBP). It is clear that in the 1980s to 1990s, indie works had actually existed in Malaysia but were not well known (Zakaria, 2016).

The ongoing issues of indie book publishing are endless. According to Nadia Khan, as a writer, she does not place herself as a literature writer but rather put more emphasis as a storyteller in the work of her published book. She also mentioned that she does not put the language in second place, but rather to create a convincing story, because the plot or the storyline should be the writer's priority (Karya indie abai nilai bahasa, 2016).

Based on a study by Othman, Thambu and Boyman (2018), the elements founded in indie books, amongst others are freedom, realistic and casual/laid back manner. It is also said that indie books are books that are not tied to any particular party and this also leads to a different flow of thinking which is freedom. Basically, the publication of indie books gives the author the opportunity to voice their opinion on an issue or open a discussion, in other words defending the individual's rights to speak freely without worrying about the sensitivity of a particular topic. It is also said that indie books 
have inspired other authors to create books in various genres and storylines. In their research, they noted that indie books are about the tastes of a young generation that loves thought-free content, occasional reading and not heavy. In fact, the prices of indie books are comparatively cheap and affordable. In addition, most of the indie books published tell the true story of the reality of the common people and provide both lessons and guidance to readers. In addition, in this rapidly evolving century, technological developments cannot be the reason that prevents writers from writing. In line with current technological advances, rapid changes are needed to keep pace with other countries.

Thus, according to Iszahanid (2016), Malaysia's participation in Jakarta as a guest at the Indonesia International Book Fair (IBF) 2016 was a good strategy to study and compare both book industries between the two countries. IBF organisers are committed to engaging and ensuring that Malaysian publications are available in Indonesia's local market. This two-way communication to the other nations is not a competition of any kind, but a way of ensuring that books produced are known throughout the country and outside the country, which in turn bears the name of the country itself. In times of modern facilities and technologies, however, should not prevent any writer from introducing their own work. Today's media platforms can also be seen as an important role in assisting with book development in the country.

As such, today's indie publication focuses exclusively on the work published by the younger generation. Therefore, indie does not only focuses on the strategy for the introduction of books but also the marketing strategy used in the country. As a result, few elements helped the book industry grow. The strength in the distribution sector goes from the publisher to the author as we are in the middle of an indie upheaval. Be that as it may, this insurgency is not new; it has been changing the substance of distribution for a long time. Over the years, as innovation changed and allowed individuals to create music and film autonomously, creators needed a bit of that pie as well, and consequently indie distributing, or independently publishing, was conceived. In the end, writers could join forces with others to compose, structure, distribute and advertise their books (Why Indie Publishing?, n.d.). Contextually, this study intends to see the key concepts implemented by Lejen Press Sdn Bhd to shift "from a product-centric business focus to one that puts the relationship with the customer first." This study aims to explore the transformational elements of the indie publication from the perspective of Lejen Press Sdn Bhd.

\section{Method}

This study adapted a qualitative research design. According to Crossman (2020), this method is best for collecting non-numerical data and it helps if the researcher wants more detailed data. This study conducted a face-to-face interview with the CEO and Managing Director of Lejen Press Sdn Bhd, Muhammad Aisamuddin bin Md Asri. Interviews are better than questionnaires because they show that researchers are prepared and meticulous and can therefore get more answers to research questions (Green, 2017). Data were then transcribed verbatim. 
INTERNATIONAL JOURNAL OF ACADEMIC RESEARCH IN BUSINESS AND SOCIAL SCIENCES

Vol. 10, No. 6, June, 2020, E-ISSN: 2222-6990 @ 2020 HRMARS

\section{Results}

\section{From Printed Media to Digital Media}

Undoubtedly, changes from one year to the next have led to a transformation of the book industry in Malaysia. In the 1990s, every time a work was published, it went through newspapers, magazines and television as a way of reading the written material. Thus, according to Sannusi and Mustaffa (2015), the development of media technology has had a huge impact on the printing industry in this country. In addition, a data analyst in his study, Rich Edmund, said that the amount of print media sales has shown that large-scale transfers between readers from conventional media to technology media. In the United States, almost the distribution of newspapers and magazines fell to 5.5 per cent. It is clear that technologically advanced changes have affected all countries, especially the publishing industry.

According to Yusof (2018), almost $100 \%$ of writers in the 1990s until the early 2000s were born from the mainstream media and the Dewan Bahasa dan Pustaka (DBP). However, in 2011 indie emerged and became known primarily by young indie writers of the younger generation. Therefore, the way the work produced is different from the work of other writers debuting from mainstream sources. Indie writers produce works based on their environment and on the reality of people's life. In addition, the writing style of a novel has also changed based on the writer's writing.

Furthermore, according to Yusop (2019), after realizing that reading groups in the new media are more of a focus than printed, many authors have used e-books and Wattpad to publish their work. Among them is the novelist Latifah Emir Ahmad who chose an electronic medium like Wattpad. She also noted that the conventional book market has forced her as a writer to think of new techniques or strategies for publishing her work. It is also seen that from her point of view, the local population has used existing smartphones and technologies to obtain interesting information, data and news at their fingertips. As a result, the book industry in Malaysia has also been affected by the steady decline of the print media.

A huge amount of printed books have a huge impact on publishers, thus increasing the risk of dumping unsold books. This is because the electronic media have allowed people to read and access information through their smartphones. According to Sannusi and Mustaffa (2015), digital content and smartphones have impacted the print media in Malaysia, including the decline in print distribution, revenue generation, creating new challenges in formulating new media revenue strategies, and also setting content strategies in digital as "Citizen Journalist" versus "Professional Journalist".

Muhammad Aisamuddin Md Asri (Personal Communication, 2020) as CEO of Lejen Press Sdn Bhd stated that two writers from Lejen Press, namely Maria Isabella and Jeffrey Zain, had used their own Wattpad to publish their work. These authors uses electronic media such as Wattpad to introduce their work to the public. He added that by using the Wattpad app, the authors were able to capture the attention of readers and to some extent promote the book they wrote.

Malaysia's economy seems to be in decline, thus influencing the book industry. According to Yusop (2019), our local book industry must also make changes that are relevant to the development of the 
digital world and economy at this time. However, according to Muhammad Aisamuddin Md Asri (Personal Communication, 2020), although sales of printed books have suffered losses, the presence of digital media such as e-books and Wattpad could help authors and publishers to introduce their work to the public all over the world. For example, Malaysian students studying abroad, such as Egypt and Canada, or Malaysians working in Australia can read indie books by simply buying an e-book or in Wattpad, and can easily access and read it.

\section{Openness and Freedom of The Work}

The works published by indie publishers are written in a casual storytelling manner. Narratives with a variety of genres such as horror, romance, thriller and so on allow readers to choose and purchase according to their tastes and interests. According to Muhammad Aisamuddin Md Asri (Personal Communication, 2020), he has recently seen many changes in the country, as well as in the book industry. However, both the publishers and writers need to look at the customer's demand and the market demand. It is because they do not want the books written by the author without analyzing the needs of readers nowadays to bring disadvantages to the publisher. According to Ashaari, Hamzah, Yaakub and Rasit (2018), indie books are notorious for expressing dissatisfaction with the government through sharp political criticism. This is because the openness and freedom of the work are no longer restricted and every writer is free to share their work or ideas. It is clear from the above statement that indie writing allows the public to voice their rights and thus contribute to a broader sense of readership.

\section{Book Marketing Strategies}

Technological changes have succeeded in introducing comics into the world. According to Hassan (2017), the book industry in Malaysia will face many challenges due to economic recession. Revenues from book sales in the store also show a 30\% decrease in book sales and further influenced the book industry. In addition, publishers are also advised to look for broader markets and use existing media platforms to ensure that books written by indie authors are well received by readers.

Therefore, according to Muhammad Aisamuddin Md Asri (Personal Communication, 2020), due to undeniable economic uncertainty, he had to find a way to ensure that Lejen Press' books were consistently in a good position on the market. Although there are small traders who often sell indie books at their warehouse, in the present situation one cannot rely entirely on retail sales to sell the books. He also said that it would be great if the author also played an important role in promoting works that, in turn, would encourage them to know the fans of the book. Thus, Lejen Press' publishing strategy has begun. This includes the introduction of \#JelajahLejenFIXI tour, Lejen Komik and Lejen Stage.

\section{\#JelajahLejenFIXI}

According to Muhammad Aisamuddin Md Asri (Personal Communication, 2020), Lejen Press has established its strategy to introduce its work to the local community by using \#JelajahLejenFIXI tour. He said that indie books were initially unknown to the public. In addition to attracting people to read more, he also received feedback from readers about indie-themed books. The existence of the \#JelajahLejenFIXI tour from one place to another has indirectly created followers or fans to become familiar with Lejen Press. 
INTERNATIONAL JOURNAL OF ACADEMIC RESEARCH IN BUSINESS AND SOCIAL SCIENCES Vol. 10, No. 6, June, 2020, E-ISSN: 2222-6990 @ 2020 HRMARS

\section{Lejen Komik}

Lejen Komik is a selection of best-selling books and comics. At the same time, according to Muhammad Aisamuddin Md Asri (Personal Communication, 2020), Lejen Press' production has travelled from one state to another, such as from Pahang to Pulau Pinang, Perak and many others. The outcome of this tour has been compiled to create a comic book of travelogue produced by the publication. Indirectly, there was a carefully calculated planning by Lejen Press. Different strategies are employed to ensure that each published book can be recognized by the local community in Malaysia.

\section{Lejen Stage}

According to Muhammad Aisamuddin Md Asri (Personal Communication, 2020), Lejen Press has collaborated with a theatre production. Some of their best-selling books were performed theatrically, such as Awek Chuck Taylor, at Petaling Jaya in 2014. And in 2015, again in collaboration with the Seyogia Theatre at Medini Mall, Johor Bahru. The same collaboration took place in 2016. This is a strategy adopted by Lejen Press to make its books known to the public. However, according to Muhammad Aisamuddin Md Asri (Personal Communication, 2020), he states that in an unstable economic situation, the book industry is facing a downturn. He does not deny that each marketing strategy implemented such as Lejen Stage and \#JelajahLejenFixi are quite costly for the publication. In addition, the book industry's issue are not only regarding the economy in this country but also the attitude of the Malaysian community, which is not as favourable to the local book industry as much.

\section{IAMLEJEN Potral}

According to Muhammad Aisamuddin Md Asri (Personal Communication, 2020), its publication now has its own portal for both its writers and fans of Lejen Press. I Am Lejen portal was created specifically for writers to present their work to the public. At the same time, the author will receive a payment based on the total number of articles being viewed. This is an indirect strategy implemented to generate effective changes and transform the book industry, in particular through the efficient use of existing electronic media.

\section{Conclusion}

In general, our Malaysian book industry is constantly competitive in publishing great books to attract local readers. It is necessary to predict and study the aspect of the themes, storytelling and marketing as they change frequently over time. This unpredictability, which in each of the coming years has given writers a higher standard to work with and is expected to produce better work to keep up with the demand of readers. However, according to Muhammad Aisamuddin Md Asri (Personal Communication, 2020), even though all publishers play a role in building different strategies, but if the economy seems unstable, the book industry will continue to be severely affected. Expecting the public's support to buy books is a far-fetched goal, not to mention to urge them to make books as a compulsory thing for them to buy. In addition, while each publishing company has developed its marketing strategies, separate efforts should be made to ensure that these strategies are implemented. The elements of marketing strategies also vary because of the enormous development of modern technology nowadays. This study discussed changes in the book industry. There are many strategies for establishing and strengthening it further. 
INTERNATIONAL JOURNAL OF ACADEMIC RESEARCH IN BUSINESS AND SOCIAL SCIENCES

Vol. 10, No. 6, June, 2020, E-ISSN: 2222-6990 @ 2020 HRMARS

\section{Acknowledgement}

This paper is supported by the Faculty of Film, Theatre and Animation and Geran GIP (600-IRMI 5/3/GIP (011/2019)) granted by Universiti Teknologi MARA (UiTM), Malaysia.

\section{References}

Ashaari, M. F., Hamzah, M. F., Yaakub, L., \& Rasit, R. M. (2018). Tarikan terhadap Buku Indie dalam Kalangan Pembaca Muda di Malaysia. The International Journal of Islamic Studies, 40(2), 169178.

Crossman, A. (2020). What is Qualitative Research?. Retrieved February 19, 2020, from https://www.thoughtco.com/qualitative-research-methods-3026555.

Green, A. (2017). The Advantages of an Interview Over a Questionnaire. Retrieved February 19, 2020, from https://bizfluent.com/info-8220458-advantages-interview-over-questionnaire.html.

Hassan, H. (2017). Penerbit buku perlu kreatif cari pasaran. Berita Harian Online. Retrieved April 16, 2019, from https://www.bharian.com.my/node/231594.

Iszahanid, H. (2016). Strategi terbaik tembus pasaran buku Indonesia. Berita Harian Online. Retrieved February 18, 2020, from https://www.bharian.com.my/node/196717.

Karya indie abai nilai bahasa. (2016). Retrieved from https://www.bharian.com.my/bhplusold/2016/01/115468/karya-indie-abai-nilai-bahasa

Masrom, M. (2018). Ahli akademik bimbang ancaman karya indie terhadap pemikiran anak muda. Retrieved from https://www.suaraperak.com/ahli-akademik-bimbang-ancaman-karya-indieterhadap-pemikiran-anak-muda/.

Othman, M. A., Thambu, N., \& Boyman, S. N. (2018). Elemen dalam Buku Indie: Satu Kajian Grounded Theory Terhadap Mahasiswa Universiti Pendidikan Sultan Idris. International Journal of Islamic Thought, 14. Retrieved from http://www.ukm.my/ijit/wp-content/uploads/2018/12/IJIT-Vol14-Dec-2018_4_38-51.pdf.

Sannusi, S. N., \& Mustaffa, N. (2015). Akhbar versi digital: Implikasi terhadap trend sirkulasi akhbar bercetak di Malaysia. Malaysian Journal of Communication, 3(2), 687-701. Retrieved from http://ejournal.ukm.my/mjc/article/view/14945.

Wahab, M. W., \& Kusnin, S. N. H. (2012). Laporan awal: Sorotan fenomena buku indie di Malaysia. Retrieved from https://vdokumen.net/laporan-awal-sorotan-fenomena-buku-indie-dibukupusat-pengajian-usuluddin-fakulti.html

Why Indie Publishing? (n.d.). Retrieved June 26, 2020, from https://www.abbottpress.com/WhyAbbottPress/IndiePublishing.aspx

Yusof, S. H. (2018). Penulis muda Malaysia baharu tidak tunduk ideologi perdana. Berita Harian Online. Retrieved November 20, 2019, from https://www.bharian.com.my/rencana/sastera/2018/09/477623/penulis-muda-malaysiabaharu-tidak-tunduk-ideologi-perdana.

Yusop, S. H. (2019). Novelis pilih e-buku, Wattpad terbit karya. Berita Harian Online. Retrieved November 15, February, from https://www.bharian.com.my/rencana/sastera/2019/02/528258/novelis-pilih-e-bukuwattpad-terbit-karya.

Zakaria., H. (2016). Dewan bahasa dan pustaka "bapak segala indie". MalaysiaKini. Retrieved February 13, 2020, from https://www.malaysiakini.com/news/347032. 